\title{
Soil water effect on crop growth, leaf gas exchange, water and radiation use efficiency of Saccharum spontaneum L. ssp. aegyptiacum (Willd.) Hackel in semi-arid Mediterranean environment
}

\author{
Danilo Scordia, ${ }^{1}$ Giorgio Testa, ${ }^{1}$ Salvatore L. Cosentino, ${ }^{1}$ Venera Copani, ${ }^{1}$ Cristina Patanè ${ }^{2}$ \\ ${ }^{1}$ Dipartimento di Agricoltura, Alimentazione e Ambiente, Università degli Studi di Catania; \\ ${ }^{2}$ CNR-Istituto per la valorizzazione del legno e delle specie arboree (IVALSA), \\ UOS di Catania, Italy
}

\begin{abstract}
Great effort has been placed to identify the most suited bioenergy crop under different environments and management practices, however, there is still need to find new genetic resources for constrained areas. For instance, South Mediterranean area is strongly affected by prolonged drought, high vapour pressure deficit (VPD) and extremely high temperatures during summertime.

In the present work we investigated the soil water effect on crop growth and leaf gas exchange of Saccharum spontaneum L. ssp. aegyptiacum (Willd.) Hackel, a perennial, rhizomatous, herbaceous grass. Furthermore, the net increase of biomass production per unit light intercepted [radiation use efficiency (RUE)] and per unit water transpired [water use efficiency (WUE)] was also studied. To this end a field trial was carried out imposing three levels of soil water availability $\left(\mathrm{I}_{100}, \mathrm{I}_{50}\right.$ and $\mathrm{I}_{0}$, corresponding to $100 \%, 50 \%$ and $0 \%$ of ETm restutition) under a semi-arid Mediterranean environment. Leaf area index
\end{abstract}

Correspondence: Danilo Scordia, Dipartimento di Agricoltura, Alimentazione e Ambiente (Di3A), Università degli Studi di Catania, Italy. Tel.: +39.095.234496 - Fax: +39.095.234449.

E-mail: dscordia@unict.it

Key words: Saccharum spontaneum; marginal land; leaf area index; biomass yield; radiation use efficiency; water use efficiency; $\mathrm{CO}_{2}$ assimilation rate.

Acknowledgements: this work was funded by the FP7 OPTIMA project Optimization of Perennial Grasses for Biomass production (Grant Agreement 289642). The authors gratefully acknowledge Mr. Santo Virgillito and Mr. Giancarlo Patanè of the Dipartimento di Agricoltura, Alimentazione $e$ Ambiente (Di3A) for helping with field measurements.

Conference presentation: SIA XLIII Congress, Pisa, 2014.

Received for publication: 18 March 2015.

Revision received: 23 July 2015.

Accepted for publication: 7 August 2015.

(C) Copyright D. Scordia et al., 2015

Licensee PAGEPress, Italy

Italian Journal of Agronomy 2015; 10:672

doi:10.4081/ija.2015.672

This article is distributed under the terms of the Creative Commons Attribution Noncommercial License (by-nc 3.0) which permits any noncommercial use, distribution, and reproduction in any medium, provided the original author(s) and source are credited.
(LAI), stem height, biomass dry matter yield, $\mathrm{CO}_{2}$ assimilation rate, and transpiration rate resulted significantly affected by measurement time and irrigation treatment, with the highest values in $\mathrm{I}_{100}$ and the lowest in $\mathrm{I}_{0}$. RUE was the highest in $\mathrm{I}_{100}$ followed by $\mathrm{I}_{50}$ and $\mathrm{I}_{0}$; on the other hand, WUE was higher in $\mathrm{I}_{0}$ than $\mathrm{I}_{50}$ and $\mathrm{I}_{100}$. At LAI values greater than $2.0,85 \%$ photosynthetically active radiation was intercepted by the Saccharum stand, irrespective of the irrigation treatment.

Saccharum spontaneum spp. aegyptiacum is a potential species for biomass production in environment characterized by drought stress, high temperatures and high VPD, as those of Southern Europe and similar semi-arid areas.

\section{Introduction}

Perennial, no-food grasses have been proposed as the most efficient species for biomass production due to their natural resource use efficiency, agronomic, environmental and social benefits (Cosentino et al., 2005, 2008; Zegada-Lizarazu et al., 2010). Recently, the Italian Ministero dello Sviluppo Economico (MISE) promoted the use of lignocellulosic, herbaceous species (Panicum virgatum, Arundo donax, Miscanthus giganteus), crop residues, dedicated forestry species and other no-food resources to reach the biofuel goal set in the RED (European Commission, 2009), with a compulsory consumption of these feedstock for second generation biofuels production starting from 2018 (1.2\%, calculated on the basis of energy content $\mathrm{Gcal})$ to progressively increase up to 2.0\% in 2022 (Italian Regulation, 2014).

While Miscanthus spp., Panicum virgatum and Arundo donax have been proposed as the most suited species for cold, warm temperate and for Mediterranean environments of EU and US due to their ability to keep high and stable yields under variable environmental conditions and management practices (Cosentino et al., 2007, 2014; ZegadaLizarazu et al., 2010; Strullu et al., 2011; Heaton et al., 2008; Arundale et al., 2014), there is still need to find new genetic resources for areas affected by severe drought, flood, salinity, pollution or other constraints. For instance, South Mediterranean area is strongly affected by prolonged summer drought which in turn limits yields of several crops. Furthermore, high vapour pressure deficit (VPD) reduces leaf conductance, affecting $\mathrm{CO}_{2}$ assimilation rate and thus yield (Kiniry et al., 1998; Flexas et al., 2007). In addition, climate change effects are supposed to increase both temperature and drought in the near future (Cosentino et al., 2012; IPCC, 2013).

Endemic species with drought resistant traits and able to maintain carbon assimilation during hot midday might enclose several advantages. Out of several perennial grasses widespread in semi-arid Mediterranean area, a plant from Saccharum genus (Saccharum spontaneum L. ssp. aegyptiacum (Willd.) Hackel), perennial, rhizomatous, 
herbaceous, C4 photosynthetic pathway of Poaceae family shows those traits of biomass crop (Cosentino et al., 2015). Native from Northern Africa, Saccharum spontaneum ssp. aegyptiacum has distributed along the seacoasts of South-Eastern Sicily, Italy.

Generally, stress tolerance of a plant species is not only determined by the plant genes but also by morphological, phenological, physiological and biochemical traits (Grzesiak et al., 2013).

Photosynthetic capacity is the first process affected by drought in relation to stomatal closure that leads also to a reduced water loss via transpiration (Flexas et al., 2007; Chaves et al., 2009). Changes in plant morphological components have been also reported, as for example a decrease in leaf area index, specific leaf area, plant height and biomass yield (Erice et al., 2010). Leaf area is the main determinant of the rate of intercepted photosynthetically active radiation (IPAR). Understanding factors controlling leaf area and limitations due to stress my help to define productivity of a plant stand per unit land area under different environments (Kiniry et al., 1999; Dohleman and Long, 2009). Biomass productivity can be determined either by the net increase in plant dry matter per unit light intercepted [radiation use efficiency (RUE)], per unit water transpired [water use efficiency (WUE)] or per nutrient taken up, as for nitrogen [nitrogen use efficiency (NUE)] (Kiniry et al., 2011). In the present work we investigated the effect of soil water availability on crop growth (i.e., stem height, leaf area index and dry biomass yield) and leaf gas exchange (i.e., net photosynthesis and transpiration rate) of Saccharum spontaneum L. ssp. aegyptiacum (Willd.) Hackel. Furthermore, the net increase of biomass production per unit light intercepted (RUE) and per unit water transpired (WUE) was also studied.

\section{Materials and methods}

\section{Field trial set-up}

Establishment was carried out in spring 2005 at the Experimental farm of Catania University, Italy (10 m a.s.l., $37^{\circ} 25^{\prime} \mathrm{N}$ lat., $15^{\circ} 03^{\prime} \mathrm{E}$ long.) in a typical Xerofluvent soil (USDA, 1999).

Rhizomes of Saccharum spontaneum L. spp. aegyptiacum (Willd.) Hack. were collected in riparian areas of South-Eastern Sicily, Italy. Fresh rhizomes were split in pieces of approximately $100 \mathrm{~g}$ with 2-3 main buds and directly transplanted at a density of 1 rhizome $\mathrm{m}^{-2}$ in a previously prepared soil bed, which was ploughed in autumn, and then disk harrowed in early spring. A randomized block experimental design with three replications was applied, with a single plot measuring $15 \mathrm{~m}^{2}$ (5x3 m). Before transplanting $100 \mathrm{~kg} \mathrm{~N} \mathrm{ha}^{-1}$ and $100 \mathrm{~kg} \mathrm{P}_{2} \mathrm{O}_{5} \mathrm{ha}^{-1}$ as ammonium sulphate and supersphosfate, respectively, were supplied. Weeds were controlled manually during the year of establishment. No fertilization and weed control have been performed in the year onwards. Plantlets were kept in well-watered condition from the establishment to the end of summer time, subsequently the irrigation was suspended. Soil water availability was differentiated from the spring 2011 , sixth growing season, by applying three levels of maximum evapotranspiration restitution (ETm): $\mathrm{I}_{100}(100 \% \mathrm{ETm}), \mathrm{I}_{50}(50 \% \mathrm{ETm})$ and $\mathrm{I}_{0}$ (rainfed condition).

Irrigation was applied from the middle of May to the middle of September, namely during the period of maximum crop ET.

Irrigation system, water amount, water application and crop coefficients were as reported by Cosentino et al. (2015).

\section{Measurements}

Main meteorological parameters were measured by means of a weather station connected to a data logger (CR10; Campbell Scientific, Logan,
UT, USA), located $100 \mathrm{~m}$ from the experimental field. Gas exchange activities, as assimilation rate $\left(\mathrm{A}, \mu \mathrm{mol} \mathrm{CO}_{2} \mathrm{~m}^{-2} \mathrm{~s}^{-1}\right)$, transpiration rate $(\mathrm{E}$, mmol $\mathrm{H}_{2} \mathrm{O} \mathrm{m}^{-2} \mathrm{~s}^{-1}$ ) and leaf temperature $\left({ }^{\circ} \mathrm{C}\right)$ were measured using a portable photosynthesis system (Li6400, Li-Cor Inc., Lincoln, NE, USA), at a flow rate of $500 \mathrm{~mL} \mathrm{~min}^{-1}$ and at ambient $\mathrm{CO}_{2}$ concentration, during cloudless days and at time of maximum solar radiation (e.g., 12:00 to 2:00 $\mathrm{pm}$ ). Measurements were scheduled from regrowth up to harvest time throughout the growing season (from March 2014 to February $2015)$ at approximately monthly intervals. VPD $(\mathrm{kPa})$ was calculated at each date of gas exchange measurement, from minimum air humidity and maximum air temperature values recorded between 12:00 and 2:00 pm. Intrinsic WUE (iWUE) was calculated as the ratio between net photosynthesis and transpiration rate at each measurement time ( $\mu \mathrm{mol}$ $\mathrm{CO}_{2} \mathrm{mmol}^{-1} \mathrm{H}_{2} \mathrm{O}$ ), while crop WUE (cWUE) as the ratio between peak biomass production and the corresponding water used by the crop (CWU). The solar radiation (PAR) at the soil level, inside the stand and over the crop canopy, was recorded by means of a Line Quantum Sensor (Li-Cor Inc.). Thus, the fraction of PAR intercepted by the crop was calculated:

$$
\text { FPAR }=\frac{\text { PARin }- \text { PARs }}{\text { PARin }}
$$

where:

FPAR = fraction of PAR intercepted by the crop;

PARin = incident PAR $\left(\mathrm{W} \mathrm{m}^{-2}\right)$;

PARs $=$ PAR at the soil level $\left(\mathrm{W} \mathrm{m}^{-2}\right)$.

The relationship between periodic measurement of leaf area index (LAI) and the FPAR was described by an asymptotic equation $[\mathrm{y}=1-$ $\left.\mathrm{e}^{\left(-\mathrm{k}^{*} \mathrm{LAI}\right)}\right]$, where $k$ represents the extinction coefficient. This formula was used to calculate the PAR intercepted by the crop, assuming a linear behaviour of LAI between subsequent sampling dates and daily PAR as $45 \%$ of the incident total solar radiation (Monteith, 1965; Meek et al., 1984; Kiniry et al., 1999):

$$
\operatorname{IPAR}=\sum_{i=1}^{n} \text { PARi } x \text { FPARi }
$$

where:

IPAR = cumulated intercepted PAR;

PARi $=$ PAR at day $i$ (calculated as $45 \%$ of total daily solar radiation); FPARi $=$ fraction of intercepted PAR at day $i$.

The relationships between the IPAR $\left(\mathrm{MJ} \mathrm{m}^{-2}\right)$ and the corresponding aboveground yield ( $\mathrm{g} \mathrm{DM} \mathrm{m}^{-2}$ ) of the different treatments were calculated by means of linear regressions. RUE values were the slopes of the regressions of aboveground yield $\left(\mathrm{g} \mathrm{DM} \mathrm{m}^{-2}\right)$ as a function of cumulated IPAR ( $\mathrm{MJ} \mathrm{m}^{-2}$ ). Crop RUE (cRUE) was also calculated as peak biomass production and the corresponding IPAR.

Dry biomass yield was determined from samples harvested after each measurement of gas exchange (at approximately monthly intervals). At each sampling, twelve randomly selected stems were taken from each treatment and replication, and the total tiller number in one square meter was also measured. To avoid any border effect, stems were cut from the centre of each plot.

Stem height was measured from the base of the cut up to last node (cm) and afterwards biomass was partitioned into stems and leaves. The former were oven dried at $65^{\circ} \mathrm{C}$ and kept until constant weight, the latter were used for LAI determination before to be dried as above.

Fresh green LAI was measured by means of a Delta-T Area Measurement System (Delta-T Devices Ltd., Burwell, Cambridge, England) as leaf area on ground area unit. The area meter was calibrated against paper standards of known area. Green LAI was accepted when $>50 \%$ green tissue was detected by visual score. 


\section{Statistical analysis}

Data for stem height, LAI, DM yield, net photosynthesis, transpiration rate and iWUE were subjected to the GLM repeated measures ANOVA univariate approach, where date represents the within-factor and irrigation the between-factor (IBM SPSS Statistics 22). When the Mauchly's sphericity test failed to meet the assumption of sphericity, the univariate results were adjusted by using the Greenhouse-Geisser Epsilon and the HuynhFeldt Epsilon correction factors. Following the univariate test satisfying the sphericity for within-subjects effects, the F-values and associated P-values for between-subjects effects were tested. It is important to point out that the tests of between-subjects effects are based on the average of the within-subjects effects. With a P-value less than 0.0001 , statistical significance is accepted (using the $\alpha$ criterion of 0.05). Crop WUE and cRUE were subjected to one-way analysis of variance (ANOVA) with irrigation as fixed factor. Differences between means were evaluated for significance using Bonferroni test. Effects were considered significant at $P \leq 0.05$. The Pearson product moment correlation coefficient at $\mathrm{P} \leq 0.05$ was executed to measure the degree of linear relationships between the two variables, namely IPAR $\left(\mathrm{MJ} \mathrm{m}^{-2}\right)$ and the aboveground yield $\left(\mathrm{g} \mathrm{DM} \mathrm{m}^{-2}\right)$.

\section{Results}

\section{Meteorological trend}

Annual rainfall was quite low during the whole growing season, reaching $414.4 \mathrm{~mm}$ from regrowth to final harvest. During crop maximum assimilation rates (February to October in the present environment) cumulated rainfall was only $180.2 \mathrm{~mm}$, while the remaining events were registered between November 2014 and February 2015, $234.2 \mathrm{~mm}$. Lower minimum temperatures were observed in December 2014 and January 2015 (about $1.0-2.0^{\circ} \mathrm{C}$ ) as compared with the previous winter (about $3.0-4.0^{\circ} \mathrm{C}$ in February 2014). Maximum temperatures progressively increased to reach the highest values in July and August 2014 (30.9-32.3 $\left.{ }^{\circ} \mathrm{C}\right)$. However, September, October and November 2014 still maintained maximum temperatures at $30^{\circ} \mathrm{C}, 25^{\circ} \mathrm{C}$ and $21^{\circ} \mathrm{C}$ respectively. The solar radiation at the soil level was the lowest in February (12.8 $\mathrm{MJ} \mathrm{m}^{-2} \mathrm{~d}^{-1}$, as monthly averaged) and the highest in June-July (26.1-26.8 $\mathrm{MJ} \mathrm{m}^{-2} \mathrm{~d}^{-1}$, as monthly averaged). VPD greatly changed during the growing season, increasing from March 2014 (1.49 $\mathrm{kPa}$ ), peaking on June, July and August (3.47, 3.55 and $3.38 \mathrm{kPa}$, respectively) to reach the lowest values on January and February 2015 ( 0.88 and $0.81 \mathrm{kPa}$, respectively), as shown in Figure 1.

\section{Morpho-biometric traits, biomass yield, crop water use efficiency and crop radiation use efficiency}

Stem height progressively increased from regrowth, reaching a plateau in November 2014 in all treatments. $\mathrm{I}_{100}$ showed the highest values $(218.2 \mathrm{~cm})$, while $I_{0}$ the lowest $(127.5 \mathrm{~cm})$. $I_{50}$ was significantly different between both treatments, $206.4 \mathrm{~cm}$ (Figure 2). Leaf area index peaked at September 2014 (6.18, 4.75 and 2.58 in $\mathrm{I}_{100}, \mathrm{I}_{50}$ and $\mathrm{I}_{0}$, respectively) and subsequently declined down to $2.49\left(\mathrm{I}_{100}\right), 1.70\left(\mathrm{I}_{50}\right)$ and $1.25\left(\mathrm{I}_{0}\right)$ at harvest time (February 2015), as shown in Figure 3. Biomass DM yield increased as described for stem height, peaking in November 2014. At this point maximum values were $17.4 \mathrm{Mg} \mathrm{DM} \mathrm{ha}^{-1}$ in $\mathrm{I}_{0}, 24.4 \mathrm{Mg} \mathrm{DM} \mathrm{ha}^{-1}$ in $\mathrm{I}_{50}$ and $34.3 \mathrm{Mg} \mathrm{DM} \mathrm{ha}^{-1}$ in $\mathrm{I}_{100}$. At harvest, DM yield slightly decreased down to $14.1,20.8$ and $28.0 \mathrm{Mg} \mathrm{DM} \mathrm{ha}^{-1}$ in $\mathrm{I}_{0}, \mathrm{I}_{50}$ and $\mathrm{I}_{100}$, respectively (Figure 4).

The effects of irrigation and date, as well as the interaction date*irrigation were highly significant $(\mathrm{P}<0.0001)$ on stem height, LAI and DM yield.

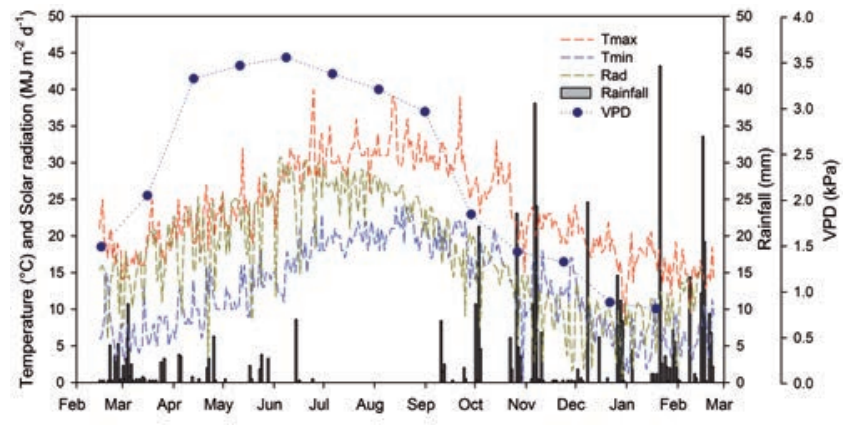

Figure 1. Meteorological trend during 2014/2015 growing season at the Experimental farm of Catania University, Italy (10 $\mathrm{m}$ a.s.l., $37^{\circ} 25^{\prime} \mathrm{N}$ lat., $15^{\circ} 03^{\prime} \mathrm{E}$ long.). VPD, vapour pressure deficit (kPa).

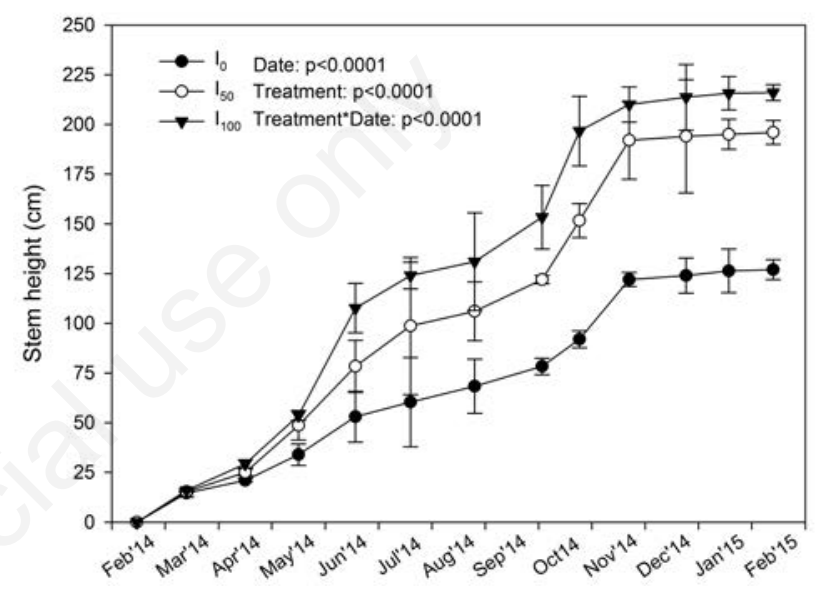

Figure 2. Stem height $(\mathrm{cm})$ of Saccharum spontaneum L. ssp. aegyptiacum under different soil water availability $\left(\mathrm{I}_{100}-100 \%\right.$ ETm restitution, $I_{50}-50 \%$ ETm restitution and $I_{0}$ - rainfed condition) at different measurement time. Date represents the within-factor and irrigation the between-factor according to the GLM repeated measures ANOVA.

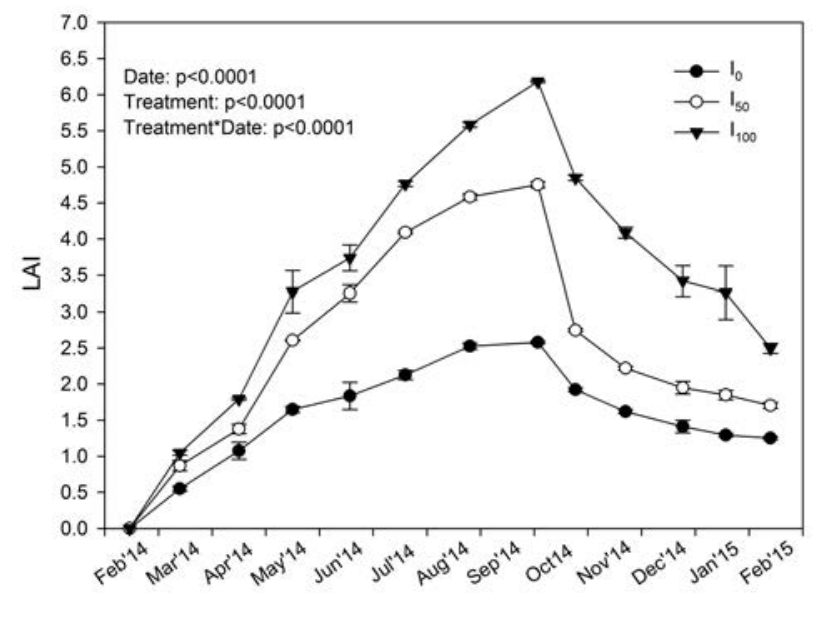

Figure 3. Leaf area index (LAI) of Saccharum spontaneum L. ssp. aegyptiacum under different soil water availability $\left(\mathrm{I}_{100}-100 \%\right.$ ETm restitution, $I_{50}-50 \%$ ETm restitution and $I_{0}$ - rainfed condition) at different measurement time. Date represents the within-factor and irrigation the between-factor according to the GLM repeated measures ANOVA. 
Crop WUE and cRUE are shown in Table 1. CWU was the highest in $I_{100}$, intermediate in $I_{50}$ and was the lowest in $I_{0}$. As result, the biomass yield as function of CWU led to significantly higher cWUE in $\mathrm{I}_{0}$ than $\mathrm{I}_{50}$ and $\mathrm{I}_{100}$ ( 6.55 vs 5.29 and $5.19 \mathrm{~g} \mathrm{~L}^{-1}$ ). $0 \mathrm{n}$ the other hand, the cRUE was significantly highest in $\mathrm{I}_{100}\left(1.29 \mathrm{~g} \mathrm{MJ}^{-1}\right)$, intermediate in $\mathrm{I}_{50}(0.96 \mathrm{~g}$ $\left.\mathrm{MJ}^{-1}\right)$ and the lowest in $\mathrm{I}_{0}\left(0.71 \mathrm{~g} \mathrm{MJ}^{-1}\right)$.

\section{Crop physiology and intercepted photosynthetically active radiation}

$\mathrm{CO}_{2}$ assimilation rate was similar before treatment differentiation (March-April 2014), afterwards it was highest in $I_{100}$, followed by $I_{50}$ with a peak on May 2014 (32.4 and $26.8 \mu \mathrm{mol} \mathrm{CO} \mathrm{Cm}^{-2} \mathrm{~s}^{-1}$ in $\mathrm{I}_{100}$ and $\mathrm{I}_{50}$, respectively) (Figure 5). As the growing season approached summertime, and so temperatures and VPD increased, the assimilation rate of the crop decreased. Indeed, as illustrated in Figure 6A, air temperature was higher than $30^{\circ} \mathrm{C}$ in the interval May to September 2014 . Leaf temperature increased as well, however a different trend was observed among treatments: both watered treatments $\left(\mathrm{I}_{100}\right.$ and $\left.\mathrm{I}_{50}\right)$ maintained lower leaf temperature than air temperature, while $I_{0}$ showed higher leaf than air temperature on June, July and August. Hence, cumulated difference between leaf and maximum air temperature (Figure $6 \mathrm{~B})$ was positive in $\mathrm{I}_{0}$ from June to August $\left(0.21^{\circ} \mathrm{C}\right.$ to $3.15^{\circ} \mathrm{C}$ ), while it was always negative in both $\mathrm{I}_{50}$ and $\mathrm{I}_{100}$.

The $\mathrm{CO}_{2}$ assimilation rate became similar between treatments from November 2014 onward.

Transpiration rate followed the same trend described for $\mathrm{CO}_{2}$ assimilation rate. Maximum transpiration rate in watered treatments was measured on May 2014 (5.5 and $4.8 \mathrm{mmol} \mathrm{H}_{2} \mathrm{O} \mathrm{m}^{-2} \mathrm{~s}^{-1}$ in $\mathrm{I}_{100}$ and $\mathrm{I}_{50}$, respectively) and subsequently declined to match with the rainfed condition $\left(\mathrm{I}_{0}\right)$ from December 2014 (Figure 7).

The effect of irrigation and date, as well as the interaction date*irrigation was highly significant $(\mathrm{P}<0.0001)$ on both net photosynthesis and transpiration rate.

An increasing trend was shown by the instantaneous WUE (iWUE), however, only date effect was significant (Figure 8). Averaging measurement times, $6.80 \mu \mathrm{mol} \mathrm{CO}$ mmol$^{-1} \mathrm{H}_{2} \mathrm{O}$ were found in $\mathrm{I}_{0}, 6.34 \mu \mathrm{mol}$ $\mathrm{CO}_{2} \mathrm{mmol}^{-1} \mathrm{H}_{2} \mathrm{O}$ in $\mathrm{I}_{50}$ and $6.45 \mu \mathrm{mol} \mathrm{CO}_{2} \mathrm{mmol}^{-1} \mathrm{H}_{2} \mathrm{O}$ in $\mathrm{I}_{100}$.

FPAR approached the asymptote as the LAI was greater than 2.0. However, at these LAI values more than $85 \%$ PAR was intercepted by the Saccharum stand, irrespective of the irrigation treatment. $I_{0}$ intercepted $90 \%$ PAR due to a maximum LAI of 2.58 , while both $\mathrm{I}_{50}$ and $\mathrm{I}_{100}$ were able to intercept all the available PAR (100\%) due to a greater LAI.

A different light extinction coefficient (k) was found among treatments: 0.89 in $\mathrm{I}_{0}, 0.87$ in $\mathrm{I}_{50}$ and 0.85 in $\mathrm{I}_{100}$ (Figure 9).

The net increase of biomass production $\left(\mathrm{g} \mathrm{m}^{-2}\right)$ per unit light intercepted $\left(\mathrm{MJ} \mathrm{m}^{-2}\right)$ led to the highest RUE in $\mathrm{I}_{100}\left(1.26 \mathrm{~g} \mathrm{MJ}^{-1}\right)$, followed by $\mathrm{I}_{50}\left(0.93 \mathrm{~g} \mathrm{MJ}^{-1}\right)$ and $\mathrm{I}_{0}\left(0.70 \mathrm{~g} \mathrm{MJ}^{-1}\right)$, as shown in Figure 10 .

According to the Pearson's test, high and positive correlation coefficients $(\mathrm{P} \leq 0.0001)$ were found in all relationships between the IPAR and the aboveground DM yield ( 0.97 in $\mathrm{I}_{100}$ and 0.98 in both $\mathrm{I}_{50}$ and $\mathrm{I}_{0}$ ).

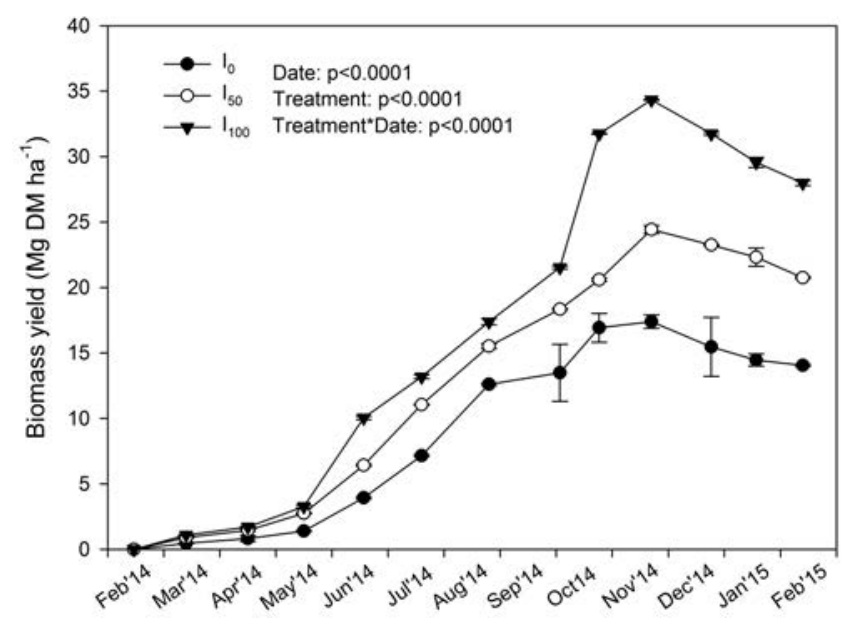

Figure 4. Aboveground biomass dry matter yield (Mg DM ha $\left.{ }^{-1}\right)$ of Saccharum spontaneum L. ssp. aegyptiacum under different soil water availability $\left(I_{100}-100 \%\right.$ ETm restitution, $I_{50}-50 \%$ ETm restitution and $I_{0}$ - rainfed condition) at different measurement time. Date represents the within-factor and irrigation the between-factor according to the GLM repeated measures ANOVA.

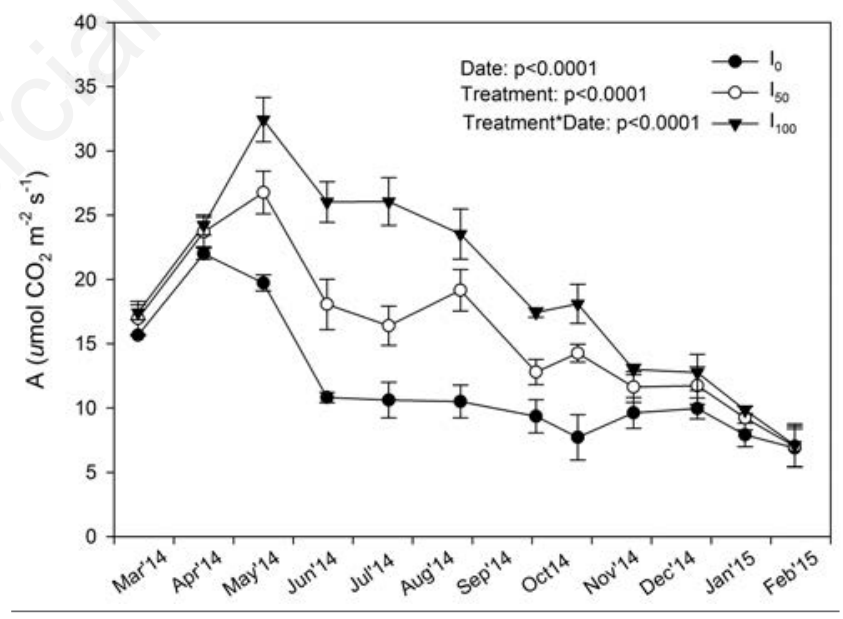

Figure 5. $\mathrm{CO}_{2}$ assimilation rate $\left(\mu \mathrm{mol} \mathrm{CO}_{2} \mathrm{~m}^{-2} \mathrm{~s}^{-1}\right)$ of Saccharum spontaneum L. ssp. aegyptiacum under different soil water availability $\left(I_{100}-100 \%\right.$ ETm restitution, $I_{50}-50 \%$ ETm restitution and $I_{0}$ - rainfed condition) at different measurement time. Date represents the within-factor and irrigation the between-factor according to the GLM repeated measures ANOVA.

Table 1. Crop water use (CWU), crop water use efficiency (cWUE), cumulated intercepted photosynthetically active radiation (IPAR) and crop radiation use efficiency (cRUE) of Saccharum spontaneum L. ssp. aegyptiacum (Willd.) Hackel.

\begin{tabular}{lcccc} 
Treatment & CWU $(\mathrm{mm})$ & CWUE $\left(\mathrm{g} \mathrm{L}^{-1}\right)$ & IPAR $\left(\mathrm{MJ} \mathrm{m}^{-2}\right)$ & cRUE $(\mathrm{g}$ MJ-1 $)$ \\
I0 & 261.6 & $6.55^{\mathrm{a}}$ & 2442.6 & $0.71^{\mathrm{c}}$ \\
I50 & 461.6 & $5.29^{\mathrm{b}}$ & 2550.3 & $0.96^{\mathrm{b}}$ \\
\hline I100 & 661.6 & $5.19^{\mathrm{b}}$ & 2650.1 & $1.29^{\mathrm{a}}$ \\
\hline
\end{tabular}

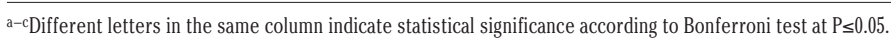




\section{Discussion}

It has been previously shown that Saccharum spontaneum spp. aegyptiacum possesses a range of agronomic, physiologic and qualitative desirable traits of biomass crop, namely $\mathrm{C} 4$ plant, high biomass yield, high water efficiently, able to assimilate $\mathrm{CO}_{2}$ during drought-stress periods, high cellulose and hemicellulose content (Scordia et al., 2010, 2014; Cosentino et al., 2015).

Present results confirmed the ability of this crop to thrive on environments characterized by severe drought stress, high temperatures and high VPD during summer time.

$\mathrm{CO}_{2}$ assimilation rate increased as the temperatures were favourable for growth (March-May), then a decreasing trend was observed throughout the growing season. Although the fully irrigation treatment did not experience water stress, the high temperatures and VPD during summertime, this latter increasing water loss from epidermal and guard cells (Mott and Parkhust, 1991), led to stomatal closure preventing dehydration of the crop but leading also to reduced carbon assimilation rates (Flexas et al., 2007).

It is worth to note that gas exchange between plant and atmosphere was still maintained even in the colder months of the growing season. This might be explained since the crop was able to keep green LAI up to harvest time $\left(1.25,1.70\right.$ and $2.49, \mathrm{I}_{0}, \mathrm{I}_{50}$ and $\mathrm{I}_{100}$, respectively).

Longer LAI maintenance allows intercepting more radiation, crop carbon assimilation and conversion into biomass throughout the growing season (Dolehman and Long, 2009).

However, we actually do not know if the carbon uptake in the coldest months was used by the crop to build up aerial biomass or if it served as carbon stock in the belowground for subsequent growing seasons. In this regard, further studies are needed to deal with this subject.

The biomass yield was comparable to that of other energy crops, as the C3 Arundo donax or the C4 Miscanthus $\mathrm{x}$ giganteus grown in the same experimental area. Cosentino et al. (2015) showed that Saccharum yields were well related to CWU, with aboveground biomass as high as $37 \mathrm{Mg} \mathrm{DM} \mathrm{ha}{ }^{-1}$ when the crop used $1150 \mathrm{~mm}$ of water (rainfall and irrigation). The reduction of biomass yield from November to harvest is in accordance with the behaviour of other perennial, herbaceous, rhizomatous grasses, owed by leaf senescence and losses, as well as by nutrient translocation from above to belowground part (Heaton et al., 2004, 2008; Cosentino et al., 2007, 2014; Dohleman and Long 2009; Angelini et al., 2009; Nassi o di Nasso et al., 2011; Strullu et al., 2011). Water use was as efficient as that of sorghum (Cosentino, 1996), but higher than those of Miscanthus $\mathrm{x}$ giganteus (Cosentino et al., 2007) and Arundo donax (Cosentino et al., 2014) grown in semi-arid environment. Indeed, $5.19 \mathrm{~g}$ of biomass were produced with $1 \mathrm{~L}$ of water in Saccharum $\mathrm{I}_{100}$ and $6.5 \mathrm{~g}$ in Saccharum $\mathrm{I}_{0}$. Miscanthus and Arundo reached $4.83 \mathrm{~g} \mathrm{~L}^{-}$ ${ }^{1}$ and $4.51 \mathrm{~g} \mathrm{~L}^{-1}$ with similar water supplied (Cosentino et al., 2007, 2014).

Slightly higher values were found with iWUE than cWUE in $\mathrm{I}_{50}$ and $I_{100}$ treatments, while in rainfed condition $\left(I_{0}\right)$ the values matched well between the two calculation methods $\left(6.80 \mu \mathrm{mol} \mathrm{CO} \mathrm{mmol}^{-1}\right.$ $\mathrm{H}_{2} \mathrm{O}$. and $6.55 \mathrm{~g} \mathrm{~L}^{-1}$, respectively). Both RUE and cRUE were the highest in the full-watered, followed by the half-watered and by the rainfed condition. The RUE calculated in both ways were very similar in all treatments. Our RUE (0.70-1.26 $\mathrm{g} \mathrm{MJ}^{-1}$ for RUE and 0.71-1.29 $\mathrm{g}$ $\mathrm{MJ}^{-1}$ for cRUE) were higher than those of Cosentino et al. (2007), who reported $1.05 \mathrm{~g} \mathrm{MJ}^{-1}$ with fully irrigated Miscanthus $\mathrm{x}$ giganteus and $0.56 \mathrm{~g} \mathrm{MJ}^{-1}$ in rainfed conditions. Kiniry et al. (1999), on the other hand, showed RUE values of 1.6-5.0 $\mathrm{g} \mathrm{MJ}^{-1}$ with switchgrass

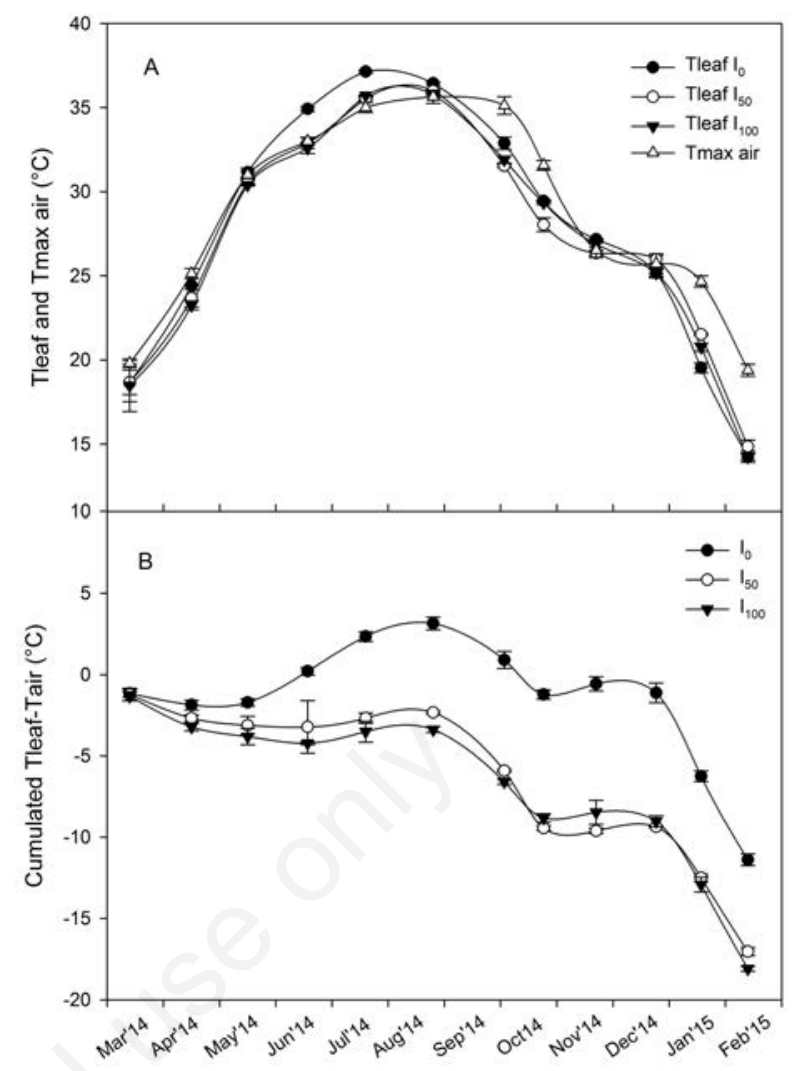

Figure 6. A) Leaf and maximum air temperature $\left({ }^{\circ} \mathrm{C}\right)$ and $\left.\mathrm{B}\right)$ cumulated difference between leaf and maximum air temperature $\left({ }^{\circ} \mathrm{C}\right)$ of Saccharum spontaneum L. ssp. aegyptiacum under different soil water availability $\left(I_{100}-100 \%\right.$ ETm restitution, $I_{50}-$ $50 \%$ ETm restitution and $I_{0}$ - rainfed condition) at different measurement time.

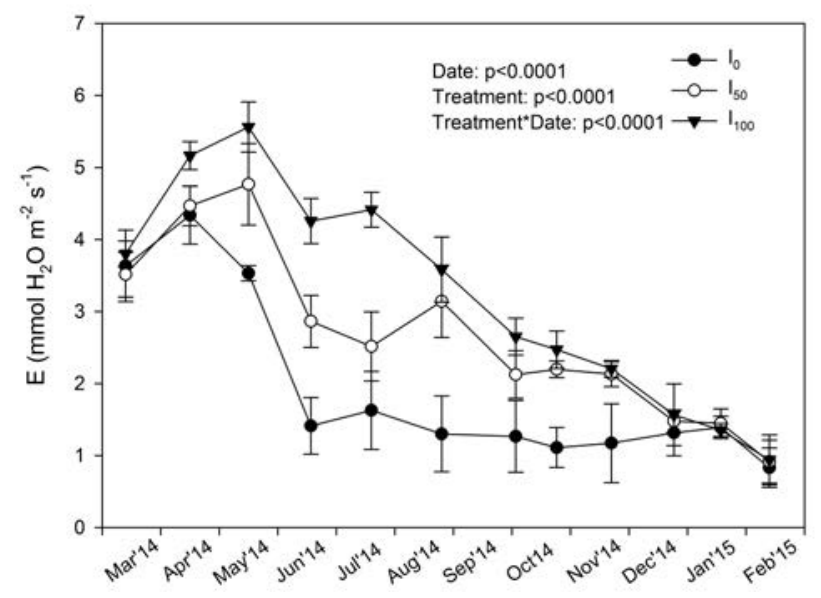

Figure 7. Transpiration rate $\left(\mathrm{mmol} \mathrm{H}_{2} \mathrm{O} \mathrm{m}^{-2} \mathrm{~s}^{-1}\right)$ of Saccharum spontaneum $\mathrm{L}$. ssp. aegyptiacum under different soil water availability $\left(I_{100}-100 \%\right.$ ETm restitution, $I_{50}-50 \%$ ETm restitution and $I_{0}$ - rainfed condition) at different measurement time. Date represents the within-factor and irrigation the between-factor according to the GLM repeated measures ANOVA. 
(Panicum virgatum), 0.5-1.8 $\mathrm{g} \mathrm{MJ}^{-1}$ with sideoats grama (Bouteloua curtipendula), 1.0-1.9 $\mathrm{g} \mathrm{MJ}^{-1}$ with big bluestem (Andropogon gerardii) and 1.9-2.6 $\mathrm{g} \mathrm{MJ}^{-1}$ with eastern gamagrass (Tripsacum dactyloides) grown in Texas, USA. In irrigated and non-irrigated Miscanthus $\mathrm{x}$ giganteus grown in Texas, Kiniry et al. (2011) found a RUE of 1.14-2.39 $\mathrm{g} \mathrm{MJ}^{-1}$ and 0.48-1.42 $\mathrm{g} \mathrm{MJ}^{-1}$, respectively. Although biomass DM yield of Saccharum was substantial, RUE might resemble low values according to what found in literature with $\mathrm{C} 4$ crops. However, it is worth to note that RUE is strongly affected by VPD, as it does for $\mathrm{CO}_{2}$ assimilation rate (Kiniry et al., 1998). For instance, Bunce (1982) found that maize $\mathrm{CO}_{2}$ assimilation rate at VPD of 2.5 $\mathrm{kPa}$ was $85 \%$ of that at VPD of $1.0 \mathrm{kPa}$, which corresponded to a $25 \%$ RUE reduction (Stockle and Kiniry, 1990). El-Sharkawy et al. (1985) reported that maize and sorghum $\mathrm{CO}_{2}$ assimilation rate at VPD of 4.0 $\mathrm{kPa}$ were $59 \%$ and $70 \%$ of that at VPD of $1.25 \mathrm{kPa}$; such relative RUE would be $48 \%$ for maize and $74 \%$ for sorghum (Stockle and Kiniry, 1990).

Furthermore, Kiniry et al. (1998) showed a liner decrease of RUE as a function of VPD, highlighting that VPD during the light period (as measured in this work) is higher than the VPD averaged over 24 $\mathrm{h}$ period, having also a greater impact on both $\mathrm{CO}_{2}$ assimilation rate and RUE. Therefore, as also argued by Foti et al. (2003) and later by Cosentino et al. (2007), VPD in Mediterranean semi-arid environment is very high (often reaching $4.0 \mathrm{kPa}$ ) and might underestimate RUE. It would be wise to focus on areas with similar environmental conditions in order to compare physiological parameters of a given crop category.

\section{Conclusions}

Saccharum spontaneum spp. aegyptiacum is a potential species for biomass production in environment characterized by drought stress, high temperatures and high VPD, as those of southern Europe and similar semi-arid areas.

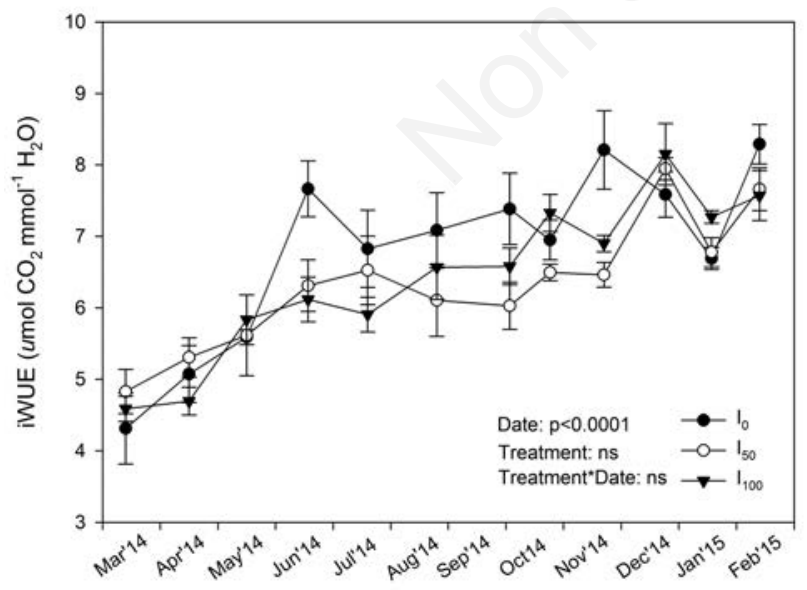

Figure 8. Instantaneous water use efficiency $\left(\mu \mathrm{mol} \mathrm{CO} \mathrm{Cmol}^{-1}\right.$ $\mathrm{H}_{2} \mathrm{O}$ ) of Saccharum spontaneum $\mathrm{L}$. ssp. aegyptiacum under different soil water availability $\left(I_{100}-100 \%\right.$ ETm restitution, $I_{50}$ $50 \% \mathrm{ETm}$ restitution and $\mathrm{I}_{0}$ - rainfed condition) at different measurement time. Date represents the within-factor and irrigation the between-factor according to the GLM repeated measures ANOVA. iWUE, intrinsic water use efficiency.
The long green LAI maintenance and $\mathrm{CO}_{2}$ assimilation, the high net increase of biomass production per unit light intercepted (RUE) and per unit water transpired (WUE) strength the idea of this species as candidate energy crop. As undomesticated crop, however, further studies are needed from an agronomic point of view, such as timing and method of propagation, water and fertilization management, harvest time and post-harvest practices, as well as from technological, energetic and environmental point of view.

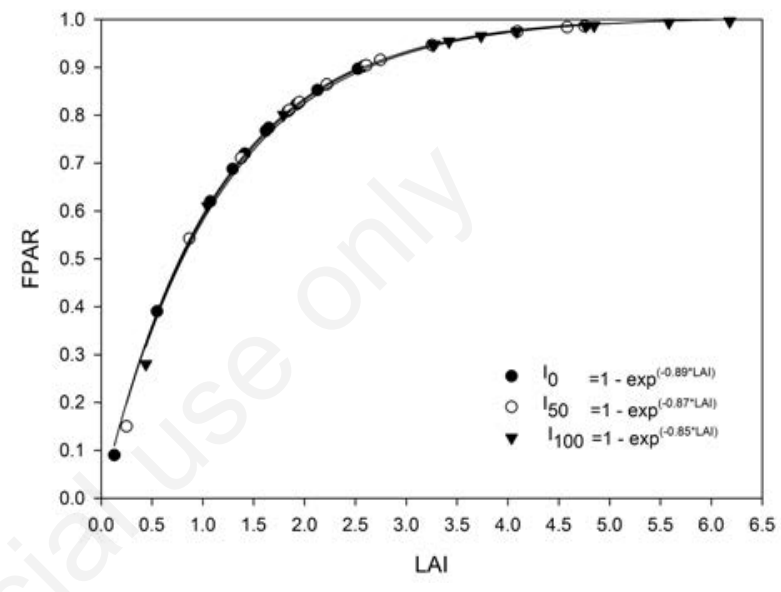

Figure 9. Relationship between periodic measurements of leaf area index (LAI) and the fraction of intercepted photosynthetically active radiation (FPAR) of Saccharum spontaneum L. ssp. aegyptiacum under different soil water availability $\left(\mathrm{I}_{100}-100 \%\right.$ ETm restitution, $I_{50}-50 \%$ ETm restitution and $I_{0}$ - rainfed condition).

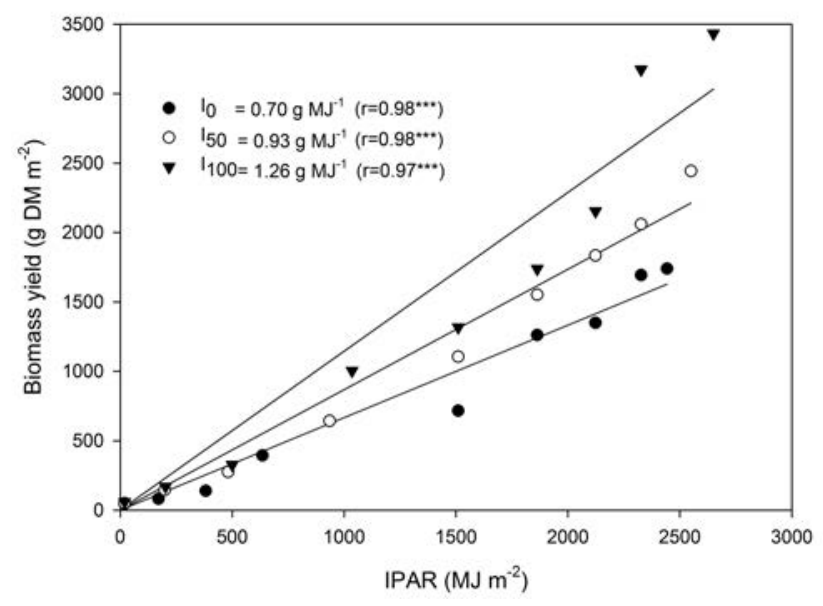

Figure 10. Relationships between intercepted photosynthetically active radiation (IPAR) ( $\mathrm{MJ} \mathrm{m}^{-2}$ ) and aboveground dry matter yield $\left(\mathrm{g} \mathrm{DM} \mathrm{m}^{-2}\right)$ of Saccharum spontaneum L. ssp. aegyptiacum under different soil water availability $\left(I_{100}-100 \%\right.$ ETm restitution, $I_{50}-50 \%$ ETm restitution and I0 - rainfed condition). The slopes represent the radiation use efficiency $\left(\mathrm{g} \mathrm{MJ}^{-1}\right)$. Pearson's correlation coefficients (r) at $\mathbf{P} \leq \mathbf{0 . 0 5}$. 


\section{References}

Angelini LG, Ceccarini L, Nassi o Di Nasso N, Bonari E, 2009. Comparison of Arundo donax L. and Miscanthus $\mathrm{x}$ giganteus in a long-term field experiment in Central Italy: analysis of productive characteristics and energy balance. Biomass Bioenerg. 33:635-43.

Arundale RA, Dohleman FG, Heaton EA, McGrath JM, Voigt TB, Long SP, 2014. Yields of Miscanthus $x$ giganteus and Panicum virgatum decline with stand age in Midwestern USA. GCB Bioenergy 6:1-13.

Bunce JA, 1982. Low humidity effects on photosynthesis in single leaves of C4 plants. Oecologia (Berl.), 54:233-5.

Chaves MM, Flexas J, Pinheiro C, 2009. Photosynthesis under drought and salt stress: regulation mechanisms from whole plant to cell. Ann. Bot. 103:551-60.

Cosentino SL, 1996. Crop physiology of sweet sorghum (Sorghum bicolor L. Moench) in relation to water and nitrogen stress. pp 30-41 in Proc. First Eur. Seminar on Sorghum for Energy and Industry, Toulouse, France.

Cosentino SL, Copani V, Patanè C, Mantineo M, D’Agosta GM, 2008. Agronomic, energetic and environmental aspects of biomass energy crops suitable for Italian environments. Ital. J. Agron. 2:81-95.

Cosentino SL, Copani V, Testa G, Scordia D, 2015. Saccharum spontaneum L. ssp. aegyptiacum (Willd.) Hack. a potential perennial grass for biomass production in marginal land in semi-arid Mediterranean environment. Industr. Crops Prod. [In press].

Cosentino SL, Foti S, D’Agosta GM, Mantineo M, Copani V, 2005. Confronto tra gli impatti ambientali di biocombustibili e di combustibili fossili per mezzo della "Life Cycle Assessment" (LCA). Agroindustria 4:109-28.

Cosentino SL, Patanè C, Sanzone E, Copani V, Foti S, 2007. Effect of soil water content and nitrogen supply on the productivity of Miscanthus $\times$ giganteus Greef and Deu. in Mediterranean environment. Ind. Crop Prod. 25:75-88.

Cosentino SL, Scordia D, Sanzone E, Testa G., Copani V, 2014. Response of giant reed (Arundo donax L.) to nitrogen fertilization and soil water availability in semi-arid Mediterranean environment. Eur. J. Agron. 60:22-32.

Cosentino SL, Testa G, Scordia D, Alexopoulou E, 2012. Future yields assessment of bioenergy crops in relation to climate change and technological development in Europe. Ital J. Agron. 7:154-66.

Dohleman FG, Long SP, 2009. More productive than maize in the midwest: how does miscanthus do it? Plant Physiol. 150:2104-15.

El-Sharkawy AM, Cock JH, Del Pilar Hernandez A, 1985. Stomatal response to air humidity and its relation to stomatal density in a wide range of warm climate species. Photosyn. Res. 7:137-49.

Erice G, Louahlia S, Irigoyen JJ, Sanchez-Diaz M, Avice JC, 2010. Biomass partitioning, morphology and water status of four alfalfa genotypes submitted to progressive drought and subsequent recovery. J. Plant Physiol. 167:114-20.

European Commission, 2009. Directive 2009/28/EC of the European Parliament and of the Council of 23 April 2009 on the promotion of the use of energy from renewable sources and amending and subsequently repealing Directives 2001/77/EC and 2003/30/EC. In: Official Journal, L 140, 5/6/2009, pp 16-62.

Flexas J, Diaz-Espejo A, Galmés J, Kaldenhoff R, Medrano H, Ribas-Carbo M, 2007. Rapid variations of mesophyll conductance in response to changes in $\mathrm{CO} 2$ concentration around leaves. Plant Cell Environ. 30:1284-98.

Foti S, Cosentino SL, Patanè C, Copani V, Sanzone E, 2003. Plant indicators of available soil water in Miscanthus $\times$ giganteus Greef and
Deu. Agronomie 23:29-36.

Grzesiak MT, Waligórski P, Janowiak F, Marci ska I, Hura K, Szczyrek P, Glab $\mathrm{T}, 2013$. The relations between drought susceptibility index based on grain yield (DSIGY) and key physiological seedling traits in maize and triticale genotypes. Acta Physiol. Plant. 35:549-65.

Heaton EA, Dohleman FG, Long SP, 2008. Meeting us biofuel goals with less land: the potential of Miscanthus. GCB Bioenerg. 14:2000-14.

Heaton EA, Voigt T, Long SP, 2004. A quantitative review comparing the yields of two candidate C4 perennial biomass crops in relation to nitrogen, temperature and water. Biomass Bioenerg. 27:21-30.

IPCC, 2013. Summary for policymakers. In: TF Stocker, D Qin, G-K Plattner, M Tignor, SK Allen, J Boschung, A Nauels, Y Xia, V Bex, PM Midgley (Eds.), Climate change 2013: the physical science basis. Contribution of Working Group I to the Fifth Assessment Report of the Intergovernmental Panel on Climate Change. Cambridge University Press, Cambridge, United Kingdom and New York, NY, USA.

Italian Regulation, 2014. Ministero dello Sviluppo Economico, Decreto 10 ottobre 2014. Aggiornamento delle condizioni, dei criteri e delle modalita di attuazione dell'obbligo di immissione in consumo di biocarburanti compresi quelli avanzati. In: G.U. Ser. Gen., n. 250, 27/10/2014, pp $81-88$.

Kiniry JR, Johnson MV, Bruckerhoff SB, Kaiser JU, Cordsiemon RL, Harmel RD, 2011. Clash of the titans: comparing productivity via radiation use efficiency for two grass giants of the biofuel field. Bioenergy Res. 5:41-8.

Kiniry JR, Landivar JA, Witt M, Gerik TJ, Cavero J, Wade LJ, 1998. Radiation-use efficiency response to vapor pressure deficit for maize and sorghum. Field Crop Res. 56:265-70.

Kiniry JR, Tischler CR, Van Esbroeck GA, 1999. Radiation use efficiency and leaf $\mathrm{CO}_{2}$ exchange for diverse $\mathrm{C} 4$ grasses. Biomass Bioenerg. 17:95-112.

Meek DW, Hatfield JL, Howell TA, Idso SB, Reginato RJ., 1984. A generalized relationship between photosynthetically active radiation and solar radiation. Agron J. 76:939-45.

Monteith JL, 1965. Light distribution and photosynthesis in field crops. Ann Bot. 29:17-37.

Mott KA, Parkhust DF, 1991. Stomatal responses to humidity in air and helox. Plant Cell Environ. 14:509-15.

Nassi o Di Nasso N, Roncucci N, Triana F, Tozzini C, Ragaglini G, Bonari E, 2011. Productivity of giant reed (Arundo donax L.) and miscanthus (Miscanthus x giganteus Greef et Deuter) as energy crops: growth analysis. Ital. J. Agron. 6:141-7.

Scordia D, Cosentino SL, Jeffries TW, 2010. Second generation bioethanol production from Saccharum spontaneum L. ssp. aegyptiacum (Willd.) Hack. Bioresour. Technol. 101:5358-65.

Scordia D, Testa G, Cosentino SL, 2014. Perennial grasses as lignocellulosic feedstock for second-generation bioethanol production in Mediterranean environment. Ital. J. Agron. 9:84-92.

Stockle CO, Kiniry JR, 1990. Variability in crop radiation-use efficiency associated with vapor pressure deficit. Field Crops Res. 21:171-81.

Strullu L, Cadoux S, Preudhomme M, Jeuffroy MH, Beaudoin N, 2011. Biomass production and nitrogen accumulation and remobilization by Miscanthus $\times$ giganteus as influenced by nitrogen stocks in belowground organs. Field Crop Res. 121:381-91.

USDA, 1999. Soil taxonomy. In: Agricultural handbook No. 436, 2nd ed. NRCS, Wash-ington, DC, USA.

Zegada-Lizarazu W, Elbersen W, Cosentino SL, Zatta A, Alexopoulou E, Monti A, 2010. Agronomic aspects of future energy crops in Europe. Biofuels Bioprod. Bioref. 4:674-91. 